\title{
A New Perspective for Prevention and to Cure COVID-19 Patients: Encouraging Medical Teams to Contact Healed People Treated with Chlorine Dioxide in Solution (CDS)
}

\author{
Enrique A. Martínez (iD) \\ Universidad Católica del Norte, Coquimbo, Chile
}

\begin{abstract}
This article is written to encourage medical teams from all over the world to contact the COVID-19 patients already treated with Chlorine Dioxide in Solution (CDS), a water soluble gas. To contact also their medical teams accompanying the study cases in order to verify the actual health conditions of patients. Finally, the invitation is to question whether CDS should be tried in their respective local healthcare environments, as it is of low cost, it seems highly effective against all viral infections and it has almost no secondary effects.
\end{abstract}

KEYWORDS: CDS; Chlorine Dioxide in Solution; COVID-19; Helsinki Declaration.

Correspondence: Dr Martinez Enrique, Foyer de Charité de Provence, BP63, Lambesc, 13410, France. Email : enrique.a.martinez@ceaza.cl

Copyright $\odot 2020$ Martinez EA. This is an open access article distributed under the Creative Commons Attribution 4.0

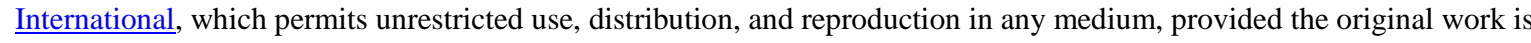
properly cited.

By June 2020, COVID-19 pandemic has resulted in over 4.3 million confirmed cases and over 290,000 deaths globally. The pandemic has changed the world forever. Social, economic, environmental and healthcare changes [1] have strongly questioned the way humanity can respond to this and to other so fast invasive threats. This article is intended to encourage medical teams to follow what has been done in some countries where patients suffering COVID19 have been successfully treated with CDS (Chlorine Dioxide in Solution).

Considering the Helsinki world medical association declaration-Section No. 37, stating that "Every Physician is authorized to use new or unproven preventive, diagnostic and therapeutic procedures", and the fact that thousands of patients suffering this COVI-19 infection were dying, in May 2020, medical doctors of Ecuador, decided to try chlorine dioxide in solution to treat 104 patients. These patients signed, under notarial verification, an authorization and discharge to receive this treatment [2]. They used the CDS acknowledging that on the one hand its known that viruses are absolutely sensitive to oxidation and on the other hand, if it works in human blood bags against viruses such as HIV and other pathogens [3], why not trying on COVID-19 patients having then so few alternative treatments. These trials resulted in the recovering of all treated patents in only four days of treatment [2].

What is CDS? This gas molecule $\left(\mathrm{ClO}_{2}\right)$ is highly soluble in water. Once in solution the gas give a yellowish color, by physical refraction. To date, it has not been introduced into the conventional pharmacopoeia as an active ingredient, although since 1994 it is used on a mandatory basis to disinfect and preserve blood bags for transfusions, after its patented use as antiviral agent in 1991 [3]. It is also used in most bottled waters suitable for consumption, since it does not leave toxic residues. Besides, the gas evaporates at temperatures higher than $11^{\circ} \mathrm{C}$.

How does CDS act on viruses (and bacteria)?. The small size of viruses (and bacteria) allows the oxygen to oxidize them very rapidly, without affecting the larger cells of living beings infected by viruses or bacteria [4]. The precise action is on the nucleic acids. Nucleic acids, DNARNA, consist of a chain of purine and pyrimidine bases, guanine $(\mathrm{G})$, cytosine $(\mathrm{C})$, adenine $(\mathrm{A})$ and thymine/uracil 
(T/U). The guanine bases, which are found in both RNA and DNA, are very sensitive to oxidation, forming 8oxoguanine as a byproduct of it. Therefore, when the $\mathrm{ClO}_{2}$ molecule comes into contact with guanine and oxidizes it and leads to the formation of 8-oxoguanine, then it blocks the replication of the viral nucleic acid by base pairing. Although replication of the protein capsid can continue, the formation of the fully functional virus is blocked by oxidation thanks to $\mathrm{ClO}_{2}$.

The oxygen of $\mathrm{ClO}_{2}$ seems to be more rapidly moving in the bloodstream by not needing hemoglobin to be transported. This hypothesis would explain, according to recorded data, why patients treated with CDS and suffering from COVID-19, recovered their oxygen saturation levels so quickly [2]. In the past, this gas and related molecules have been proven against several viruses, bacteria but also against other larger parasites such as fungi and yeasts [5]. Besides, CDS has extremely low toxicity against humans at short and at long term $(5,6,7,8,9,10)$. These studies showed no deleterious effects on physiological features like pulse, respiratory frequency, and temperature, not on biochemical parameters such as Glucose, Ureic Nitrogen, Phosphates, Alkaline Phosphatase, Transaminases or thyroid excretions. Nor hemolysis or anemias were neither detected at doses of 24 ppm per day, for two weeks. Chlorine dioxide was safe even for drinking water as demonstrated on a 198 people study for 115 days [11].

The world overreaction applied on people as the social lockdown seems to provoke more problems than the virus itself [12]. The few treatments still available, the high costs

\section{REFERENCES}

[1] Nicola M, Alsafi Z, Sohrabi C, Kerwan A, Al-Jabir A, Iosifidis C, Agha M, Agha R. The socio-economic implications of the coronavirus pandemic (COVID-19): A review. Int J Surg. 2020;78:185-193. Available at : https://doi.org/10.1016/j.ijsu.2020.04.018 (visited on September $\left.17^{\text {th }}, 2020\right)$.

[2] Over 100 [people] Recovered from Covid-19 with CDS by Physicians of the Ecuadorian Association of Integrated Medicine, AEMEMI (Asociación Ecuatoriana de Médicos Expertos en Medicina Integrativa, according to the Spanish acronym). Available at: https://lbry.tv/@Kalcker:7/100$\underline{\text { Recovered-Aememi-1:7 and www.andreaskalcker.com }}$ (visited on September $17^{\text {th }}, 2020$ ). The data of this study on 104 patients is on the journal website and also available upon author request.

[3] Kross RD, Scheer DI. Composition and procedure for disinfecting blood and blood components. Available at: https://patents.google.com/patent/US5019402A/en. 1991 (visited on September $17^{\text {th }}, 2020$ ).

[4] Noszticzius Z, Wittmann M, Kály-Kullai K, Beregvári Z, Kiss I, Rosivall L, et al. Chlorine Dioxide Is a SizeSelective Antimicrobial Agent. 2013. PLoS ONE 8(11): e79157. Available at: https://doi.org/10.1371/journal.pone.0079157 (visited on September $\left.17^{\text {th }}, 2020\right)$.

[5] Barry Wintner B, Contino A, O’Neill G. Chlorine Dioxide, Part 1: A Versatile, High-Value Sterilant for the Biopharmaceutical Industry. BioProcess International Technical December 2005. Pp. 42-46. Available at: https://www.academia.edu/3829889/Chlorine_Dioxide_Pa rt_1_A_Versatile_High_Value_Sterilant_for_the_Biophar maceutical_Industry (visited on September $17^{\text {th }}, 2020$ ). and low speed of vaccines development all seems to indicate that alternative treatments and even nutrition factors [13] should be more urgently considered to avoid panic and more socioeconomic disasters.

This article is written to encourage medical teams from all over the world to contact the COVID-19 patients already treated with this soluble gas. To contact also their medical teams accompanying the study cases as to verify the actual health conditions of patients. Finally, the invitation is to question whether CDS should be tried in their respective local healthcare environments. Particularly because it has low cost. By being easy to apply, the effective antiviral action and by having no strong adverse effects. All biophysical, biochemical and physiological research on the topic is also very welcome.

\section{ACKNOWLEDGMENTS}

None.

\section{AUTHOR'S CONTRIBUTION}

The participation of the author corresponds to the criteria of authorship and contributorship emphasized in the Recommendations for the Conduct, Reporting, Editing, and Publication of Scholarly work in Medical Journals of the International Committee of Medical Journal Editors.

\section{COMPETING INTERESTS}

The author declares no competing interests with this case.

\section{FUNDING SOURCES}

None.

[6] Patel Y, Wong D. Toxicological review of chlorine dioxide and chlorite. EPA/635/R-00/007. 2000. Available at: https://cfpub.epa.gov/ncea/iris/iris documents/documents/ toxreviews/0648tr.pdf (visited on September 1 $7^{\text {th }}, 2020$ ).

[7] Lubbers, JR; Chauhan, S; Bianchine, JR. Controlled clinical evaluations of chlorine dioxide, chlorite and chlorate in man. Fundam Appl Toxicol 1:334-338. (1981)

[8] Lubbers, JR; Chauhan, S; Bianchine, JR. Controlled clinical evaluations of chlorine dioxide, chlorite and chlorate in man. Environ Health Perspect 46:57-62. (1982)

[9] Lubbers, JR; Chauhan, S; Miller, JK, Bianchine, J.R. The effects of chronic administration of chlorine dioxide, chlorite and chlorate to normal healthy adult male volunteers. J Environ Pathol Toxicol Oncol 5:229-238. (1984a).

[10] Lubbers, JR; Chauhan, S; Miller, JK; Bianchine, JR. The effects of chronic administration of chlorite to glucose-6phosphate dehydrogenase deficient healthy adult male volunteers. J Environ Pathol Toxicol Oncol 5:239-242. (1984b).

[11] Michael, GE, Miday, RK, Bercz, JP, Miller, RG,Greathouse, DG, Kraemer, DF, \& Lucas, JB. Chlorine Dioxide Water Disinfection: A Praspective Epidemiology Study, Archives of Environmental Health: An International Journal, 36:1, 20-27, DOI: 10.1080/00039896.1981.10667601 (1981)

[12] Boretti, A. Sustainable Post Covid19 Lockdown Strategy Through Evidence-Based Policy: Analysis of Covid19 Fatalities Across Europe. Integr J Med Sci 2020, Volume 7, ID 172 DOI: $10.15342 /$ ijms.7.172

[13] Zhang Y., Chen, G. Nutritional Considerations in COVID19 Pandemic. Integrative Journal of Medical Sciences 2020, Volume 7, ID 198. DOI: 10.15342/ijms.7.198. 